\title{
Reflexions on lockdown
}

Clearly the "hospitality industry"- - bars and restaurants etc. — has been severely and adversely affected by lockdowns. Typically bars etc. have been either compelled to close completely, or else operate under restrictions so severe (e.g., closing at $6 \mathrm{pm}$ as in Italy, or prohibited from selling alcohol as in Scotland) they can barely be considered to be hospitable venues. Even when allowed to operate with a semblance of normality, the requirement to wear masks, or erect screens between guests, largely eliminates conviviality.

It is increasingly being pointed out that the economic damage caused by these restrictions far exceeds the loss of livelihood for proprietors and staff of the establishments, and their suppliers of victuals and other consumables. Socializing in cafés and public houses is a vital part of human well-being. Under lockdown, the chance encounter between two previously unacquainted habitués has been essentially eliminated by physical distancing rules. The then newly established coffee houses in seventeenth-century London spawned whole new industries, such as the various branches of Lloyds. In our own time, it has been said that the emergence and phenomenal growth of start-up companies in the early 1970s in Silicon Valley was powerfully catalysed by popular hostelries where the young technologists congregated after work, relishing discussion of the challenges they faced, but also enabling them to casually meet entrepreneurs and financiers, who were to provide ingredients no less essential than the hardware and software for energizing the new industry. In contrast, the established behemoths of the electronics and computer industries were large, self-contained establishments on the East Coast, full of brilliant engineers, scientists and businesspeople and equipped with worldleading research laboratories, but essentially isolated from one another and without a tradition of staff informally gathering in bars and cafés.

According to this argument, the loss of possibilities for spontaneous physical encounters and the cross-pollination of ideas that results will severely hamper the economy both during lockdown and after, in what is hoped will be a period of rapid recovery, because the old habits of informal socializing have been lost and, furthermore, with the vast increase in working from home, people are much more isolated from each other during the working day and there will be considerable barriers of organization and distance obstructing gatherings in the future.

Is this a reasonable viewpoint? It may be somewhat exaggerated, the exception rather than the rule-imagine the creation of a café ex nihilo in a place that formerly lacked one. There is no guarantee that scintillating conversations will start to happen. In the 1980s, my father ceased to attend the coffee breaks in his research institute, remarking that the conversation had mostly degenerated into discussing last night's television programmes. ${ }^{1}$ On my first day as a young postdoc at a leading East Coast university, when I started to talk about a burning topic in the

1 Since we had no television set at home this was even more devoid of interest than it might otherwise have been. 
field, I was told rather brusquely that "we don't talk about work during coffee break". As an undergraduate, one is apt to suppose that the brilliance of the conversation among the fellows dining on High Table may lead to some riddle of the universe being solved while we talked about more mundane things; much later I found that over a hundred years ago A.C. Benson had written "By the evening the majority of Dons are apt to be tired. They have been hard at work most of the day, and they look upon the sociable evening hours as a time to be given up to ... nimble interchange of humorous or interesting gossip; a man who pursues a subject intently is apt to be thought a bore", 2 an observation that I can well corroborate from later times when, as a graduate, one is occasionally invited to dine on High Table.

The fact is that a creatively brilliant person will find the means to progress with his or her thoughts as surely as water will continue to flow downstream regardless of the pebbles seemingly blocking the way - one simply finds a way round. It used to be de rigueur to spend an afternoon each week in the library looking through the latest journals; when that ceased I wondered how the cross-fertilization from quirkily chancing on articles unrelated to one's main research could continue. ${ }^{3}$ Nowadays, in the era of Internet searching, I find that it happens just as effectively, in different ways; likewise the socializing formerly provided by cafés and the like will also find new ways to happen.

The real threat from lockdown, and the pandemic in general, is the ever more oppressive State presence. It is dismaying to see the eagerness with which State support has been taken up. It is already officially acknowledged that a significant proportion (i.e., more than 10\%) of the take-up is fraudulent, but there have been numerous examples of legally permitted receipt of the monies, which are then used, for example, to pay dividends, which is certainly not in the spirit of the emergency instruments. ${ }^{4}$ One recalls the counterexample of the Prince of Windisch-Grät $z^{5}$ - then, too, it was an exception to the general behaviour. Just as the prolonged closure of bars and cafés is permanently changing behaviour - the old spontaneity may be lost forever-the stupendous reliance on State aid risks permanently fulfilling the predictions of Richard Law and Viscountess Davidson, helping to usher in "the kind of society in which everybody pays to the State what he must, and takes from the State what he can" (Law) and "gradually killing the finest characteristics of our people - the spirit of enterprise and of individual attainment. It appears to be a case of 'What can I get, what can I take and what can I procure for myself?' and not 'What can I give, how

2 A.C. Benson, From a College Window, pp. 91-92. London: Smith, Elder, \& Co. (1906).

3 A similar effect arose from looking up a specific article in the bound copies of back numbers of a journal.

4 At the same time there appear to be many whose livelihoods have been destroyed at a stroke by seemingly arbitrary and even senseless regulations, yet without recourse to official assistance to stave off destitution.

5 "Dagegen ist es ein interessanter Zug, daß in einer Zeit, wo die hohe österreichische Aristokratie durch den Wettlauf um die Betheiligung mit Concessionen zu industriellen Gesellschaften Geld zu machen suchte und das enrichessez-vous, durch welches die Regierung sie für den Verlust jedes politischen Einflusses entschädigen wollte, mit Gier in Scene setzte, der Fürst sich weigerte, seine Creditactien verkaufen zu lassen, als ihr Cours nahezu aufs Doppelte gestiegen war. 'Ich habe sie genommen, weil man mir sagte, die Gründung der Creditanstalt wäre ein Vortheil für den Staat', entgegnete er seinem Geschäftsführer auf den betreffenden Vorschlag; 'Geschäfte macht kein Windisch-Grätz’.” W. Rogge, Oesterreich von Világos bis zur Gegenwart, Bd. I, S. 9. Leipzig und Wien: Brockhaus (1872). 
can I help, how can I serve?"' (Davidson). ${ }^{6}$ Even if only some of the new measures and attitudes become permanent, then our future looks distinctly illiberal. ${ }^{7}$

It is not only in financial matters that the State has become obtrusive. There is now much talk of making a coronavirus vaccine compulsory for all citizens, in order that the immunization criterion can be fulfilled, ${ }^{\mathbf{8}}$ and population immunity achieved, whereupon the disease should swiftly die out. ${ }^{9}$ This raises a fundamental point of ethics - the question of personal freedom and individual choice versus the collective good of the State. In a nutshell, this is the argument of Machiavelli in Il Principe. ${ }^{10}$ He opted decisively for the latter. It may be that in 16th century Florence it was an easy choice under the then prevailing conditions. Today, when the potential powers of the State are far more extensive and ramified, but also those of the individual, the biggest challenge is to ensure consistency. It does indeed appear to be perfectly rational to strive to protect society from the consequences of a potentially debilitating disease. Likewise it appears to be perfectly rational to strive to improve the genetic stock of humankind. The arguments in favour of eugenics are very similar to those in favour of vaccination. The former has been decisively rejected by our society, but we are all free to practice it individually. Likewise with vaccination, and if (well-founded) scepticism regarding the efficacy of a SARS-CoV-2 vaccine prevents takeup sufficient to achieve population immunity, then so be it. An intermediate approach, with the State paying people to be vaccinated, has been suggested;11 it would appear to evade the ethical problem and is already well established as a principle, although almost invariably a fine, or tax, or extra cost is associated with exercising individual freedom. ${ }^{\mathbf{1 2}}$

The very rapid extension of the reach of the State is of course a nightmare for libertarians. Libertarianism, or simply liberalism, is roughly synonymous with the free market economy, the main argument for which, repeated ad nauseam - the late Hans Rosling was a great exponentis the "great enrichment", namely the enormous-several thousand per cent-increase of average per capita wealth since about $1800 \mathrm{AD}$, when it was around 3 USD per day. The chief strength of this argument is the apparent irrefutability of the actual numbers, about which there is little dispute. Even the United Nations endorses it - the first of the Sustainable Development Goals (SDGs, adopted in 2015) is "No poverty". Never mind the sage observation that "For ye have the poor always with you". ${ }^{13}$

${ }^{6}$ National Health Service Bill (debate on 2nd Reading). HC Deb 30 April 1946 vol. 422 cc 43-142.

7 It is a particular irony that in the UK this is happening just as the nation, through Brexit, frees itself from the suprastate supremacy of the EU. At the time of the debate about Britain's initial entry, many ordinary citizens were in favour because they did not feel particularly well represented by the existing Westminster Parliament. Nevertheless, the EU has only very sporadically played the role of "guardian of the guardians", upholding equity and justice for the ordinary citizen where it might have been usurped by national governments, in a few special cases.

8 J.J. Ramsden, On the immunization criterion for Covid-19. Nanotechnol. Perceptions 16 (2020) 228-229.

9 This assumes that permanent immunity is conferred by exposure to the disease, whether by infection or by vaccination. Since no vaccine has yet been developed, although great efforts are being made, the matter remains speculative at present.

${ }^{10}$ N. Machiavelli, Il Principe. Milan: Rizzoli (1979) (first published in 1532).

${ }^{11}$ J. Savulescu, Good reasons to vaccinate: mandatory payments for risk? J. Med. Ethics $\mathbf{4 6}$ (2020) in press.

${ }^{12}$ Examples include the fine for not voting in a Swiss referendum (no longer imposed); punitive duty on tobacco and alcohol (varies widely by country); paying for private education of one's children.

${ }^{13}$ Matthew 26, 11. 
The cause of the great enrichment remains an intriguing object of enquiry. The free market economy is often considered to have begun in 1776 with Adam Smith, who championed individual freedom to pursue self-interest. ${ }^{14}$ A century earlier, John Locke had laid strong foundations for the equality of individuals, although a landmark for that and the repudiation of external coercion alongside rank and privilege was the Rütli oath in 1291, whence ultimately sprang the Swiss Confederation. For Deirdre McCloskey, the key cause is "commercially tested betterment" ${ }^{15}$ for which she proposes "innovism" as a portmanteau word combining new ideas (innovations) with the (essential) commercial testing.

Although liberalism is often contrasted with socialism, especially its apotheosis in the USSR, there too economic growth — which is what the great enrichment amounts to - was the goal, as it is in modern (communist) China, with—so far at least — apparently striking success, although the extreme coercion practised by the omnipresent State should prevent it from happening if the libertarian thesis is correct.

Prior to the dramatic rise of the West in the 19th century, China was a vast, wealthy and civilized country where, as far as one can judge from its literature, economic growth was not a goal, although there was plenty of innovation and flourishing commerce; people were able to lead reasonably fulfilling lives with goals other than the accumulation of wealth. This, by fair means or foul, was already being lampooned in Britain before Adam Smith's great work was published. ${ }^{16}$ Yet McCloskey, Cowen ${ }^{17}$ and others are firmly wedded to the concept that maximizing economic growth should be our overwhelming societal objective, since it covers a multitude of lesser objectives, such as improved health outcomes, ${ }^{18}$ more leisure time and so forth, and at the same time covering a multitude of sins such as growing income inequality (dwarfed by the growth in absolute incomes) ${ }^{20}$ and a growing divide between rentiers and nonrentiers. In effect, they subscribe to Richard Posner's view that wealth maximization provides the soundest ethical basis for the organization and operation of social institutions. ${ }^{21} \mathrm{It}$ is a commonly held view that the Beveridge report ${ }^{22}$ paved the way for several decades of "compassionate growth". The contradiction between freedom-driven economic growth and coercing everyone into following

${ }^{14}$ Smith, A. The Nature and Causes of the Wealth of Nations. London: William Strahan (1776).

${ }^{15}$ D.N. McCloskey, Why Liberalism Works: How True Liberal Values Produce a Freer, More Equal, Prosperous World for All. New Haven: Yale University Press (2019).

${ }^{16}$ For example, Alexander Pope's Epistles III and IV in Moral Essays (first published in 1733-4). See also B. Mandeville, The Fable of the Bees: or, Private Vices, Publick Benefits (6th edn). London: J. Tonson (1732).

${ }^{17}$ T. Cowen, Stubborn Attachments: A Vision for a Society of Free, Prosperous, and Responsible Individuals. San Francisco: Stripe Press (2018).

${ }^{18}$ This is incontrovertibly seen in the "Bristol curve", linking life expectancy to gross domestic product (GDP) per capita. ${ }^{19}$

${ }^{19}$ P. Thomas, Does health spending need to outpace GDP per head? Nanotechnol. Perceptions 13 (2017) 17-30.

${ }^{20} \mathrm{~S}$. Kuznets, Income growth and income inequality. Am. Econ. Rev. 45 (1955) 1-28.

${ }^{21}$ R.A. Posner, The Economics of Justice. Cambridge, Mass.: Harvard University Press (1981) (reviewed by R. Schmalbeck, The justice of economics: an analysis of wealth maximization as a normative goal. Columbia Law Rev. 83 (1983) 488-525); and R.A. Posner, Economic Analysis of Law (2nd edn). Boston, Mass.: Little, Brown \& Co. (1977) (reviewed by R.M. Dworkin, Is wealth a value? J. Legal Studies 9 (1980) 191-226).

${ }^{22}$ W. Beveridge, Social Insurance and Allied Services. London: His Majesty's Stationery Office (1942). 
the goal of growth does not occur to its advocates. The coercion can of course be soft and subtle but nonetheless effective; around the year 2000 I had occasion to make several visits to Shanghai, a city then driven by the relentless pursuit of wealth, and regretfully realized that for that reason I could never feel truly at home there, despite its amazing features (such as wonderful gardens, museums, zoos and aquaria) that arose from that wealth.

The flies in the ointment of the great enrichment have been eloquently expounded by Mishan. ${ }^{23}$ Perhaps the most important — and at the same time remarkably easy to remedy - is the woefully inadequate accounting of the external diseconomies of economic activities as part of their costs. These diseconomies are chiefly those adversely impacting the environment, and those inflicting disamenity on the neighbours of the activity. Interestingly, the main argument of the advocates of economic growth for neglecting environmental damage is very similar to that for neglecting increasing social discord, namely that richer countries tend to spend more on preserving the environment. This is perfectly true; for example in the 1950s the Zürichsee was woefully polluted by effluent from the Uetikon chemical factory, but by the 1970s the lake had become one of the cleanest in Switzerland. Nevertheless, in most highly developed countries the state of the environment still leaves a great deal to be desired, and there is still little restraint regarding further construction, with respect to both quantity and quality, for which the defaults seem to be maximizing and minimizing, respectively. Why should wealthy countries inflict subtopias on themselves? Nowadays, given our extensive knowledge about the environment, it would be extremely easy to hold developers to account not only for deleterious environmental impacts but also for the disamenities suffered during construction (noise, pollution etc.). Nearly all large-scale housing projects are deeply unpopular with neighbours of the schemes, not least because the environment is permanently despoiled and local lives made a misery during the actual construction, "for free". Large infrastructure projects, often imposed on communities by central government, are even less popular. In poor countries, vast infrastructure projects tend to give scant attention to environmental aspects, ${ }^{24}$ which in some cases seem to be deliberately set aside, such as with the vast sugar plantations in Ethiopia irrigated from dams on the River Omo, which have led to rapidly falling water levels in Lake Turkana, probably presaging its ultimate disappearance, much as happened to the Aral Sea. Given the several decades (at least) that infrastructure lasts we need to prepare for a future in which requirements may be very different. Do we really need a new runway when air traffic has fallen by about $90 \%$ with no significant recovery in sight? Do we really need a new high-speed railway when rail passenger traffic has fallen by a similar amount? Do we really need a giant new waste incinerator when we are doing our utmost to eliminate waste altogether?

The second important fly in the ointment is the fact that the limited liability company which, as a juridical person, has a legal status very similar to that of a natural person, is typically much larger - by many orders of magnitude — than an individual natural person. Hence, even though we have an excellent system of laws to ensure justice, ${ }^{25}$ the scales are generally

${ }^{23}$ E.J. Mishan, The Costs of Economic Growth. London: Staples Press (1967).

${ }^{24}$ A.J. Browne, LAPSSET: The history and politics of an eastern African megaproject. London: Rift Valley Institute (2015).

${ }^{25}$ P.R. Wood, The Fall of the Priests and the Rise of the Lawyers. Oxford, UK and Portland, Oregon: Hart Publishing (2016). 
weighted heavily in favour of the company, which can command far greater resources when it comes to, for example, fighting a planning application in the courts. Here the solution cannot be envisaged as simply as the accounting exercise needed to eliminate the first "fly". Besides, it must be recognized that the joint-stock, limited liability company, as a vehicle for concentrating capital and other resources, plays an essential role in the development of our civilization.

Lockdown gives us an opportunity to rethink these matters with fresh insight. It is been delightful to note the resurgence of wildlife - for example, due to the drastic reduction in tourism and fishing there has been a boom in the births of olive ridley sea turtles on beaches in Sonora state, Mexico. ${ }^{26}$ Whereas the initial draconian restrictions on travel led to feelings of "let's wait and see, and look forward to when we can fly again", as time wore on I found myself fundamentally rethinking the whole matter. All the unpleasantnesses that were incrementally heaped on passengers during the past decades have come to the fore. Do I really want to put up with all that again? Certainly not for pleasure (cf. Figure 1). A motoring holiday last October in Austria and Hungary was marred by horrendous traffic jams in Budapest, taking one and a half hours to reach a restaurant (it would have taken less time on foot), and many hours of delay on the German Autobahnen, stuck in queues of hundreds of kilometres, on the way back home. On the railways it is little better. The demise of the Pullmans, which used to run from London to every major city in England, is symbolic of the decline of real comfort; in Hungary restaurant cars were withdrawn in September 2017 due, essentially, to insufficient patronage; they lasted longer there than in most other European countries and even where they still survive they are a shadow of their former excellence. And one's journey is likely to finish and end in stations of architectural mediocrity, if not downright ugliness, rather than of inspirational beauty.

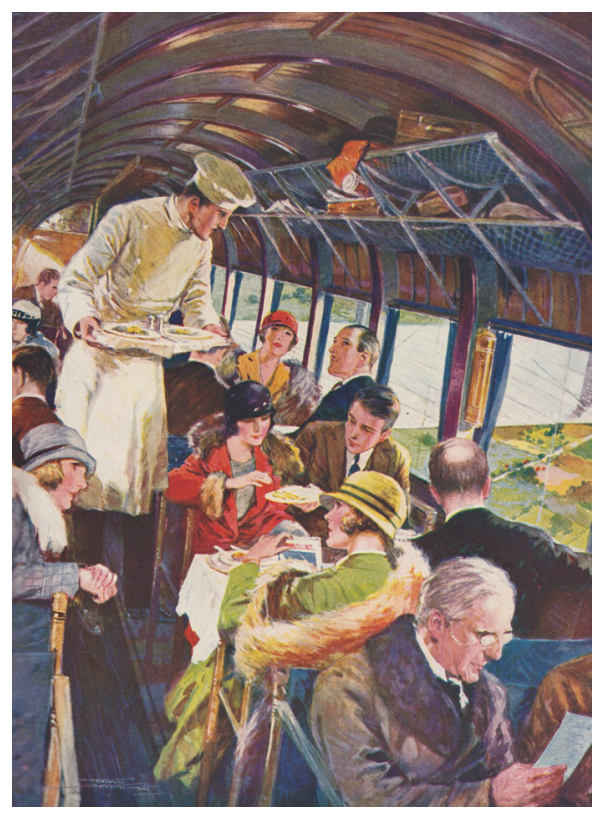

Figure 1. On a flight from London to Paris (from H. Golding (ed.), The Wonder Book of Aircraft. London: Ward, Locke \& Co., 1927).

${ }^{26}$ E. Gatten, Quiet beaches ignite turtle baby boom. Daily Telegraph (30 October 2020).

Nanotechnology Perceptions Vol. 16 (2020) 
But the vision of a destination sufficiently wonderful can still outweigh the disbenefits of the travel itself. Alas, authentic wonderfulness has almost universally vanished. It seems obvious that "crowding destroys the values the people crowding come to seek". ${ }^{27}$ Mishan writes that "From the destruction wrought by large population movements to that wrought by mass tourism is a short step and one that opens up a vista of the immeasurable destructive potential of indiscriminate economic growth", pointing out the conflict of interest between the tourists and their facilitators and those who care about preserving natural beauty. ${ }^{\mathbf{2 8}} \mathrm{He}$ quotes from a short report entitled "The Last Days of Andorra"-written in 1959. ${ }^{29}$ If it was already bad then it has, largely incrementally, become immeasurably worse during the past few decades, and this fact can now be tangibly grasped through the reflexion resulting from many months of forced prevention from travelling. Without such a break the decline was never apparent forcibly enough to bring about a change of habits, although it might have been vaguely perceived. Mishan again: "One policy measure alone which would go far to reverse this dismal trend may be hazarded: an international ban against all air travel" ${ }^{30}$ Thanks to Covid-19, this is precisely what has happened - otherwise surely considered to be wholly impracticable.

The great enrichment is not of course an abstract concept but means that the citizen is able to access an ever greater choice of goods and services: the libertarian considers social welfare to be synonymous with effective choice. The great fallacy in this consideration is that the citizen can choose only from what the market presents. For example, when new kinds appear, the older ones are withdrawn, at the discretion of industry. Therefore it cannot be said that the wants of consumers exist independently of the products created by industry: ${ }^{\mathbf{2 3}}$ the market is a wantcreating mechanism rather than a want-satisfying one, and advertising plays a key role in want creation. Mishan made the very concrete proposal to abolish commercial advertising in order to remove this artificiality of the market. ${ }^{31}$ In our Internet era, technically this would be easy enough to implement, with the added advantage of breaking the business model of some of the tech giants that attract much criticism nowadays.

The question is, can we have an economy vibrant in the sense that we all have the freedom to live a fulfilled life (bearing in mind that we all have very different needs - the mathematician may merely need pencil and paper; the experimental scientist may need expensive instruments - hence there can be no blueprint of our economic system) and in which we can continue to progress in our understanding of the universe? These are the societal goals of real value, and ${ }^{\mathbf{3 2}}$

An irdische Schätze das Herze zu hängen,

ist eine Verführung der törichten Welt.

A new report from the European Academies' Science Advisory Council (EASAC) advocates replacing GDP with indicators of human wellbeing, arguing that measuring GDP has led to excessive consumption and financial growth, destroying Earth while doing nothing to make us happier. ${ }^{33}$ The time to make such a change could not be better:

${ }^{27}$ R.F. Dasmann, The Destruction of California. New York: Collier (1975).

${ }^{28}$ Footnote 23, p. 103.

${ }^{29}$ Published in The Economist (22 August 1959).

${ }^{30}$ Footnote 23, p. 105.

${ }^{31}$ Ibid., p. 111.

32 J.S. Bach, Cantata for the 24th Sunday after Trinity (BVW 26) (1724).

${ }^{33}$ Towards a Sustainable Future: Transformative Change and Post-COVID-19 Priorities. Halle: EASAC (2020). 
- Covid-19 has made us realize that change is needed; even the most sanguine of those holding the conventional viewpoint now realize that Covid may be a permanent feature, and even if it is not the new habits are by now too firmly ingrained to allow us to simply revert even if the virus vanishes without trace;

- Additive manufacturing, print-on-demand and similar technologies are able to produce vast ranges of goods, including those designed by consumers, without the need for huge numbers to be manufactured merely to break even;

- The Internet provides a global online market; searching for what one authentically wants is far more efficient than being bombarded by hopeful advertisements for what one very likely does not want.

A further ingredient is a circular economy emphasis on repurposing, reuse, remanufacture, repair etc. ${ }^{34}$ It implies mobilizing far more labour than the present system of high-volume automated manufacture of single-use goods, often in overseas factories. Products, and entire supply chains, need to be redesigned (above all for repairability) to enable this new, circular economy. It would of course be great if bars and cafés could reopen, to be abuzz with conversation about design, repair and so forth. Mishan remarks that "The opportunities for increasing social welfare through raising standards of taste and appreciation are not likely to be tapped in a highly commercial society". ${ }^{35}$ How very true. To fulfil its potential, the circular economy should not be highly commercial, nor does it need to be in the conventional sense. Far better to prepare now for the circular economy, rather than keep shops open 24/7 in December (as is being proposed), to frenetically "make up" for the November lockdown.

The euphoria coming from our technical capabilities should be tempered by the observation that "Sustained technological advance ... tends inexorably to destroy the sources of satisfaction of ordinary people". ${ }^{36}$ In an age by smart factories, smart meters, smart motorways etc. and even, soon, air taxis, ${ }^{37}$ it may be useful to recall the story of a pupil of Confucius who saw a gardener, who, to get water for his flower-beds, repeatedly went down to the spring with his bucket. So he asked him whether he would not like to lessen his labour. "How can I?" replied the other. "You take a long piece of wood for a lever," said Confucius' pupil, "weighted behind, but light in front; with this you dip for the water and it comes up without the least trouble. They call this device a draw-well." But the gardener, who was something of a philosopher, answered: "I have heard my teachers say: 'If a man uses machines, he carries on all the affairs of life like a machine; whoever carries on his affairs like a machine gets a machine-like heart; and when anyone has a machinelike heart in his breast, he loses true simplicity." ${ }^{38}$ And in the spirit of our own time, ${ }^{39}$

In an age of swift invention it is frequently believed

That the pressure of a button is as good as work achieved;

\footnotetext{
${ }^{34}$ W.R. Stahel, The circular economy and intelligent decentralization, nanotechnologies and materials, minerals and mining. Nanotechnol. Perceptions 16 (2020) 151-168.

${ }^{35}$ Footnote 23, p. 119.

${ }^{36}$ Ibid., p. 148.

${ }^{37} \mathrm{M}$. Cogley, Why the flying car revolution is finally all set to take off in Britain. Daily Telegraph (2 November 2020).

${ }^{38}$ Quoted in A. Schweitzer, Civilization and Ethics (3rd edn), p. 268. London: Adam \& Charles Black (1949).

${ }^{39}$ R.A. Hopwood, Our fathers. In: The Old Way and Other Poems. London: John Murray (1916).
} 
But the optimist inventor should remember, if he can,

Though the instrument be perfect, there are limits to the man.

The circular economy might offer just the right balance between technological appreciation and human control to make it deeply satisfying for nearly everyone.

These proposals would have appeared admirable but wholly unattainable before Covid-19. The pandemic gives us a glimmer of hope that they might just be realizable.

\section{J.J. Ramsden}

\section{Afterthought ${ }^{40}$}

A few days ago, on 5 November, a new lockdown was imposed in England, prior to which a policy of regional restrictions was being followed and it seemed that much of the economy was recovering back to pre-Covid levels. The new lockdown (until 2 December) was voted on in the House of Commons on 4 November-by 516 in favour to 38 against. It was supported by the opposition Labour Party. ${ }^{41}$

It is truly astonishing how little real scrutiny the justification for the new lockdown has received, not least since there has been plenty of work done on alternative scenarios. ${ }^{42}$ During the House of Commons debate on the afternoon of 4 November, Huw Merriman asked about the evidence that more lives would be saved by the lockdown then will be lost from public health, a lack of jobs and a mental health crisis. The Prime Minister replied that "we explore every other avenue before we go down that route [of lockdown] ... doing nothing ... would mean those who are sick, suffering or in need of help could be turned away because there is no room in hospitals." But in reality there seems to have have been no meaningful exploration of other avenues - probably a reflexion of the deplorable lack of mathematical, statistical and scientific knowledge among members of the House of Commons, and a fortiori the Government, which makes any meaningful exploration impossible. One might have thought that the official opposition would have robustly opposed the measures, perhaps on the basis of the alternative scenarios, ${ }^{42}$ but no, the opposition leader Keir Starmer merely remarked that "while these regulations are not in any way desirable or perfect, they are now necessary because the Government have lost control of the virus, and we will support them" (emphasis added). ${ }^{\mathbf{1 1}}$ Coupled with the inability to properly assess the epidemiology $\mathbf{4}^{\mathbf{3}}$ is the fear of liability for the outcome.

Keir Starmer asserted that "The country is at ... the tipping point in the fight against the virus". ${ }^{41}$ Very possibly the economy is at the tipping point. At some point a subtle change "of phase" takes place and the way back is no longer accessible. Whether it was right or wrong, lockdown has now been enacted and there is no return. In this essay I have tried to suggest an alternative way forward into an economy with far greater personal engagement and responsibility.

\footnotetext{
${ }^{40}$ Received 9 November 2020.

${ }^{41}$ Public Health. House of Commons Hansard 683 (4 November 2020) cols 331-384.

${ }^{42}$ For example, the paper by $\mathrm{P}$. Thomas in this issue (Measuring and controlling the Covid-19 pandemic in the UK through the winter of 2020-1. Nanotechnol. Perceptions 16 (2020) in press).

${ }^{43}$ The lack of assessment has fallen under an even more unfavourable light after it was revealed that the projected fatalities were overstated. ${ }^{44}$

${ }^{44}$ L. Donnelly and H. Yorke, 'Death toll graphs were wrong'. Daily Telegraph (6 November 2020).
} 